\title{
On the Accuracy of Glacial Isostatic Adjustment Models for Geodetic Observations to Estimate Arctic Ocean Sea-Level Change
}

\author{
Zhenwei Huang ${ }^{1,4, *}$, Jun-Yi Guo ${ }^{1}$, C. K. Shum ${ }^{1,3}$, Junkun Wan ${ }^{1}$, Jianbin Duan ${ }^{1}$, Hok Sum Fok ${ }^{1}$, \\ and Chung-Yen $\mathrm{Kuo}^{2}$ \\ ${ }^{1}$ Division of Geodetic Science, School of Earth Sciences, Ohio State University, Columbus, Ohio, USA \\ ${ }^{2}$ Department of Geomatics, National Cheng Kung University, Tainan, Taiwan, ROC \\ ${ }^{3}$ Institute of Geodesy and Geophysics, Chinese Academy of Sciences, Wuhan, China \\ ${ }^{4}$ Chinese Academy of Surveying and Mapping, Beijing, China
}

Received 3 May 2012, accepted 28 August 2012

\begin{abstract}
Arctic Ocean sea-level change is an important indicator of climate change. Contemporary geodetic observations, including data from tide gages, satellite altimetry and Gravity Recovery and Climate Experiment (GRACE), are sensitive to the effect of the ongoing glacial isostatic adjustment (GIA) process. To fully exploit these geodetic observations to study climate related sea-level change, this GIA effect has to be removed. However, significant uncertainty exists with regard to the GIA model, and using different GIA models could lead to different results. In this study we use an ensemble of 14 contemporary GIA models to investigate their differences when they are applied to the above-mentioned geodetic observations to estimate sea-level change in the Arctic Ocean. We find that over the Arctic Ocean a large range of differences exists in GIA models when they are used to remove GIA effect from tide gage and GRACE observations, but with a relatively smaller range for satellite altimetry observations. In addition, we compare the derived sea-level trend from observations after applying different GIA models in the study regions, sea-level trend estimated from long-term tide gage data shows good agreement with altimetry result over the same data span. However the mass component of sea-level change obtained from GRACE data does not agree well with the result derived from steric-corrected altimeter observation due primarily to the large uncertainty of GIA models, errors in the Arctic Ocean altimetry or steric measurements, inadequate data span, or all of the above. We conclude that GIA correction is critical for studying sea-level change over the Arctic Ocean and further improvement in GIA modelling is needed to reduce the current discrepancies among models.
\end{abstract}

Key words: Arctic Ocean, Sea-level change, Glacial Isostatic Adjustment (GIA)

Citation: Huang, Z., J. Y. Guo, C. K. Shum, J. Wan, J. Duan, H. S. Fok, and C. Y. Kuo, 2013: On the accuracy of glacial isostatic adjustment models for geodetic observations to estimate Arctic Ocean sea-level change. Terr. Atmos. Ocean. Sci., 24, 471-490, doi: 10.3319/TAO.2012.08.28.01(TibXS)

\section{INTRODUCTION}

Sea-level change is an important indicator of anthropogenic climate change especially in the Arctic region, which is undergoing significant changes in climate and environmental conditions. Causes of Arctic Ocean sea-level change include rapid sea ice thinning (Kwok and Untersteiner 2011), increased river discharges (Peterson et al. 2006), ocean warming (Barry et al. 1993), decreased sea-level pressure (Walsh et al. 1996), and changes in ocean circulation (Bindoff et al. 2007).

\footnotetext{
* Corresponding author

E-mail: huang.612@osu.edu
}

Contemporary observations used to study Arctic sealevel changes are obtained from long-term tide gage, and more recently, data from satellite radar altimetry and Gravity Recovery And Climate Experiment (GRACE) (e.g., Proshutinsky et al. 2001, 2004; Kuo 2006; Morison et al. 2007; Killett et al. 2011). Those observations also include contributions from ongoing glacial isostatic adjustment (GIA) process, which is the Earth's continuing viscoelastic response to the loading of glaciation and deglaciation since the last Ice Age. To study climate related sea-level change, this GIA effect should be removed from the derived sealevel trend, the straightforward way to do so is based upon GIA forward models. However, large uncertainty exists in 
contemporary GIA models and difference between GIA models is significant (e.g., Spada et al. 2011; Tamisiea 2011; Guo et al. 2012), and also that inconsistent terminology or methodology has been used when removing the GIA contribution from both altimetry and GRACE measurements (Tamisiea 2011).

A large portion of Arctic Ocean is permanently or seasonally covered by sea-ice although the sea-ice cover and thickness have been rapidly thinning. The presence of the sea-ice cover makes it difficult to observe sea-level change using past and current high latitude observing radar altimetry, including Geosat GM/ERM, ERS-1/-2, GFO, and Envisat (covers up to $81.5^{\circ} \mathrm{N}$ ). Therefore, global sea-level rise estimates traditionally ignore the Arctic Ocean. More recently, Arctic altimetry data sets have been improved and higher quality altimetry data are obtained and validated in sea-ice free oceans (e.g., Lebedev et al. 2011; Cheng et al. 2012; Volkov and Pujol 2012).

Recent mass component sea-level budget assessments (e.g., Willis et al. 2008; Cazenave et al. 2009; Leuliette and Miller 2009; Peltier 2009; Leuliette and Willis 2011) focused on the ocean region between $66^{\circ} \mathrm{N}$ and $66^{\circ} \mathrm{S}$, thus missing major part of the Arctic Ocean. These studies used different GIA models to remove GIA effect from both altimetry and GRACE observations. For altimetry observation, ICE5GVM2 (Peltier 2004) was used in all studies to account for the ocean volume change resulting from GIA-induced seafloor deformation, for GRACE observation, ICE5GVM2 is used in Peltier (2009) and Cazenave et al. (2009) to remove the GIA effect from GRACE derived equivalent water thickness trend to study the present day mass component of the sea-level trend, while the others use the Paulson's model (Paulson et al. 2007) to remove GIA effect. Only the Stokes coefficient is available for Paulson's model, so it cannot be readily used to correct for altimetry measurements consistently (Tamisiea 2011; Guo et al. 2012). In addition, this inconsistency of using GIA models, the magnitude of GIA contribution to ocean mass change estimation is as large as the signal, or the mass component of present-day sea-level rise, ranging from 1.0 to $2.0 \mathrm{~mm} \mathrm{yr}^{-1}$ in the sea-level trend. Consequently, it is crucial to assess the range of uncertainty in GIA contribution to GRACE measurements.

The primary goal of this paper is to evaluate the role of the GIA process in estimating secular rate of sea-level change from three above-mentioned geodetic observations in the Arctic Ocean. We first describe the theory of GIA modelling in general and the different GIA model predictions that are needed to remove GIA effect from different geodetic observations in detail, and then compare the difference of model prediction from 14 contemporary GIA models available to us, focusing on the Arctic Ocean region. Finally, the range of uncertainty when using GIA model to remove its effect from sea-level observation is assessed.

\section{GLACIAL ISOSTATIC ADJUSTMENT AND ITS CONTRIBUTION}

During the last ice age, gigantic ice sheets accumulated over North America, Scandinavia, Greenland and Antarctica, reaching its maximum about 21000 years ago, with ice thicknesses as large as $3-4 \mathrm{~km}$ and it is called the Last Glacial Maximum (LGM). Since then, these ancient ice-sheets began to melt and the melting was completed approximately 4000 years ago when ice sheets disappeared over North America and Scandinavia and decreased its size over Greenland and Antarctica. The melted water flowed into the ocean and caused a sea-level rise. Overall, the sea level has risen approximately 120 meters since LGM (Peltier 2004).

When the solid Earth underneath the ice-sheet was depressed during the Ice Age, mantle material flowed away from the loading center to the surrounding region and created a forebulge. When the ice melted away or decreased in size, this forebulge collapse and the mantle material flowed back to the glaciated region, causing the former to subside and the latter to uplift (Peltier 2001). This geophysical process involving the response of the viscoelastic Earth to the loading resulting from deglaciation of ancient ice-sheets is called GIA. For GIA at present time, we assume that there is no water exchanging between ocean and land, so the ongoing GIA process is just a viscous response that causes present-day crustal uplift or subsidence mainly near the LGM ice-sheet centers. In addition, Earth's gravity field also changes resulting from this large-scale mass redistribution inside the Earth during the GIA process.

Theoretically modelling this GIA process and the induced sea-level change were first introduced by Farrell and Clark (1976) to solve the sea level equation with given ice history (the space-time evolution of ice load thickness) and assumed known viscoelastic structure of the Earth. In the sea level equation, GIA is assumed to be the only process (no ocean or other dynamic processes are considered), and sea surface is treated as an equipotential surface. The solution of the sea level equation provides the rate of relative sea level change (i.e., the sea level with respect to the bottom crust), the rate of crustal uplift and the rate of absolute sea level change (i.e., the sea level with respect to the geocenter used in the GIA model). The relationship between those terms is shown as follows:

$S_{R}(\theta, \lambda, t)=S_{A}(\theta, \lambda, t)-R A D(\theta, \lambda, t)$

where $S_{R}$ denotes relative sea level, $S_{A}$ denotes absolute sea level or sea surface, RAD denotes the crustal uplift, $\theta$ is colatitude, $\lambda$ is longitude and $t$ is time. $S_{A}$ is often referred to as geoid in the literature. However, this GIA geoid change is different from the classical definition of geoid change, which is zero-mean. 
When ice sheets melted away, water is assumed to be redistributed from land to ocean instantaneously, causing rise in sea-level and changes in surface load, therefore both the sea surface (assumed to be an equipotential surface) and surface of solid Earth are deformed from this changing load. The relationship is given as sea level equation:

$$
\begin{aligned}
& \Delta S_{R}(\theta, \lambda, t)= \\
& \quad O(\theta, \lambda, t)\left[\left\langle L(\theta, \lambda, t) *\left(G_{S_{A}}-G_{R A D}\right)\right\rangle_{\text {ocean }}+C(t)\right]
\end{aligned}
$$

where $\Delta S_{R}(\theta, \lambda, t)$ is the change in relative sea level, and $O(\theta, \lambda, t)$ is the "ocean function" that it is unity where there is ocean and zero where is land, $G_{S_{A}}$ and $G_{R A D}$ are green functions to describe the response of sea surface and solid surface to the changing load, $\langle *\rangle_{\text {ocean }}$ indicates the integration over ocean, $L(\theta, \lambda, t)$ is the surface load given as $L(\theta, \lambda, t)=\rho_{I} \Delta I(\theta, \lambda, t)+\rho_{w} \Delta S_{R}(\theta, \lambda, t)$, in which $\rho_{I}$ and $\rho_{w}$ denote the density of ice and water respectively, $\Delta I(\theta, \lambda, t)$ is the space-time history of ice thickness variations given in ice history models. Note that $\Delta S_{R}(\theta, \lambda, t)$ exists in both sides of Eq. (2), thus, iterations are needed to solve the sea level equation. In the sea level equation the total water within the Earth system is assumed to be conserved, $C(t)$ is included here to conserve mass.

Two inputs required to solve this problem are, (1) the ice loading history, which is the space-time evolution of ice cover thickness; and, (2) the viscoelastic structure of the solid Earth which is used to compute the solid Earth deformation in response to the ice load change. The most used global ice history model right now is ICE-series, which was developed by Peltier and his colleagues (Tushingham and Peltier 1991; Peltier 1994, 2004).

In GIA modelling, the sea surface is assumed to be an equipotential surface, and the value of this potential that defines this surface changes with time. It should be understood that the sea level right now is about 120 meters higher than the one at LGM. However, for the GRACE study, the geoid is defined as the equipotential surface that does not change its value over time. It is this time-dependent potential value of sea surface in GIA modelling that may cause the confusion when one using GIA models to remove its contribution from both altimetry and GRACE observations [see Tamisiea (2011) for more details]. Furthermore, the rotational state of the Earth changes due to the mass redistribution in GIA process, which leads to changes in centrifugal potential that will affect the sea level and thus cause the deformation of both solid Earth and sea surface, this is the so-called rotational feedback. Recent studies show that both the formulation and the influence of this rotational feedback effect on sea level are still under debate (Mitrovica and Wahr 2011; Tamisiea 2011; Guo et al. 2012).

In the following, we will describe how the GIA process influences the geodetic observations in detail and how to totally remove its contribution from these observations to study present-day sea-level change.

\subsection{GIA on Tide Gages}

Tide gage records the local sea level change relative to the benchmark that is attached to the Earth's crust. The tide gage observation is the change of distance between sea surface and the surface of solid Earth. The ongoing GIA process causes the glaciated region to rebound and the surrounding region subside, the tide gage near the glaciated region, i.e., the forebulge region at the LGM, will record a relative sea level (RSL) decrease, while the tide gages surrounding glaciated region will capture an increasing RSL in its record. It is known that a region far away from glaciated region could also be affected (Peltier and Tushingham 1991; Peltier 1998).

The mass redistribution of mantle material causes the crustal uplift underneath the tide gage that is recorded by the tide gage. This mass redistribution also perturbs the equipotential surface that is at the sea surface. Therefore, in order to remove the GIA contribution from tide gage records, both sea surface change and solid Earth surface change need to be accounted for. The GIA model predicted rate of relative sea level accounts both effects and is used to remove GIA contribution from tide gage records. Some recent studies used GPS measurement at or near tide gage benchmarks to obtain vertical land motion and used it to correct the tide gage record to compare with altimetry results. However, this only removes part of the GIA effect (Tamisiea and Mitrovica 2011).

It is worth mentioning that tide gage records also include the elastic contribution from present-day loading change, such as ice sheet or glacier melt, atmosphere, tidal, ocean or hydrologic loading. To study the sea-level change caused by present-day climate change, these effects must be removed from the tide gage RSL record.

\subsection{GIA on Satellite Altimetry}

Satellite altimetry measures the absolute sea level relative to a common datum. The most commonly used datum at present is the International Terrestrial Reference Frame (ITRF). In the ongoing GIA process, the mantle material redistribution changes the sea floor and the equipotential surface on which the absolute sea level lies. In GIA modelling, an assumption is made that there is no current water exchange between land and ocean, so the averaged GIA predicted absolute sea level change over ocean is actually the averaged changes of surface of the sea floor.

The average of absolute sea surface from GIA model prediction over specific region gives a correction to altimetry measured sea level trend. Peltier (2001) computed a global average of his GIA model prediction over $66^{\circ} \mathrm{N}$ to 
$66^{\circ} \mathrm{S}$ (the coverage limit of TOPEX/Poseidon satellite altimetry), and obtained an average value of $-0.30 \mathrm{~mm} \mathrm{yr}^{-1}$, which is suggested to be used for GIA correction to globally averaged altimetry measured sea-level rise. Over the Arctic Ocean, this correction is relatively small when compared to the altimeter measurements, which will be shown in detail in the next section.

\subsection{GIA on GRACE}

GRACE measures the gravity change due to mass redistribution within the Earth system. Normally it is interpreted as the surface mass loading in terms of equivalent water thickness change on an elastic Earth (Wahr et al. 1998). GIA process is largely the redistribution of mantle mass, the density of the mantle is much higher than the density of water. If one interprets the GRACE measurement without removing the GIA effect, it would lead to significant different or even erroneous estimates. To obtain the sea-level change due to ocean mass change, the GIA effect should be removed before interpretation, the straightforward way is using GIA models. Two approaches are normally used, one is to remove GIA effect in the GRACE-derived spherical harmonic coefficients before converting them to equivalent water thickness. The other is to compute equivalent water thickness from GIA geopotential changes directly. In this study, we adopt the latter way in order to investigate how large is the uncertainty due to GIA models.

In contrast to the contribution to altimetry measurements, GIA contribution in GRACE observation is different in two aspects. The first aspect is a spatial constant value due to the different definition between GIA predicted absolute sea level and geoid. This constant is shown as the spherical harmonic degree zero in the decomposed GIA predicted absolute sea-level change, in GRACE, the changing rate of degree zero Stokes coefficient is zero to indicate that the total Earth system conserve mass. The second aspect is that the GRACE measurement is acquired in inertial reference frame, but the GIA model prediction is used for observation obtained in Earth-fixed rotating frame. The additional centrifugal potential, which results from the changes in polar motion due to mass redistribution in GIA process, could affect the sea level or sea surface that is observed by altimeter, but GRACE does not sense the influence from this change of centrifugal potential. Therefore, for the GIA models with rotational feedback, if they are used to correct GRACE observation, this centrifugal potential must be removed before calculation.

It is worth to mention that in both Altimetry and GRACE data processing, the effect of pole tide (including both solid Earth and ocean pole tides) computed using observed polar motion based on elastic Earth model was removed. Thus, when computing GIA correction for both Altimetry and GRACE from the GIA models with rotational feedback, the contribution from GIA caused polar drift to pole tide assuming elastic response of the solid Earth should be excluded (Guo et al. 2012).

\section{DATA DESCRIPTION}

Data used in this study are GIA models, secular sealevel trend derived from long-term tide gage and high latitude satellite altimetry, and ocean bottom pressure derived from monthly GRACE gravity observations.

\subsection{GIA Models}

In this study we use 14 GIA models available to us to compute the GIA effect that needs to be removed from tide gage, satellite altimetry and GRACE observations respectively. The comparison of these 14 GIA models was conducted based on two approximate inherent relations in GIA model in Guo et al. (2012). Here our purpose is to investigate their differences when they are applied to remove GIA contribution from geodetic observations to study sealevel change over the Arctic Ocean, the descriptions of GIA model in Guo et al. (2012) are adopted in here.

Descriptions of models are provided in Table 1, where references for more information are provided. We adopt the "short name" convention as in Guo et al. (2012). The convention is as follows, the first 3 letters denote the author(s), the following number/letter denotes the ice history used in the model (e.g., 5 means ICE-5G), the next 3 letters (if any) indicate Earth model/rheology or other information, and the last ' $R$ ' (if included) is used to indicate that rotational feedback is considered in the model. Most of the models are from two sources, the first one is website of the Special Bureau for Loading (SBL) of the Global Geophysical Fluid Center (CGFC) of the International Earth Rotation and Reference System Service (IERS) ${ }^{1}$, the second one is from the author(s) via private communication.

Most commonly used models in GRACE community are Pau-5-R and Peltier-5-VM2-R. About Pau-5-R model, we have only the gravitational potential data, so in this study, this model is only used to correct GRACE observations, it is not used to correct tide gage and satellite altimetry observations. Centrifugal potential effect is removed from Peltier-5-VM2-R and Peltier-5-VM4-R in order to correct GRACE observation. The W\&O-EGOD model is an estimation from geodetic observation data (EGOD) (Wu et

\footnotetext{
${ }^{I}$ Currently, the SBL website is down and will be back with all the data later. At present, all data from this website can be downloaded from ftp://dutlru2. lr.tudelft.nl/pub/wouter/pgs.tar.gz.
} 
Table 1. A brief description of the 14 GIA models used in this study as modified from (Guo et al. 2012). Abbreviations: ATU - author(s); IH - ice history; UMV - upper mantle viscosity in $10^{21} \mathrm{~Pa} \mathrm{~s}$; LMV - lower mantle viscosity in $10^{21} \mathrm{~Pa}$ s; LT - lithosphere thickness in km; NLE - number of layers of Earth model; PREM - preliminary reference earth model; LH - lateral heterogeneity; CM - center of mass motion; RF - rotational feedback; SR - source; PC - private communication; SBL - website of special bureau for loading; REF - reference.

\begin{tabular}{|c|c|c|c|c|c|c|c|c|c|c|}
\hline Model & AUT & IH & UMV & LMV & $\mathbf{L T}$ & NLE & LH & RF & SR & REF \\
\hline Pau-5-R ${ }^{(1)}$ & Paulson & ICE-5G & 0.9 & 3.6 & 98 & 5 & No & Yes & $\mathrm{PC}$ & (Paulson et al. 2007) \\
\hline Pel-4-VM2 & Peltier & ICE- $4 G^{(2),(3)}$ & $0.4-1.5$ & $1.3-3.9$ & 90 & PREM $^{(9)}$ & No & No & $\mathrm{PC}$ & (Peltier 2002) \\
\hline Pel-5-VM2-R & Peltier & ICE-5G & $0.4-1.5$ & $1.3-3.9$ & 90 & PREM & No & Yes & $\mathrm{SBL}^{(10)}$ & (Peltier 2004) \\
\hline Pel-5-VM4-R & Peltier & ICE-5G & $0.4-1.5$ & $1.3-3.9$ & 90 & PREM & No & Yes & SBL & (Peltier 2004) \\
\hline SKM-O-R & $\begin{array}{l}\text { Sasgen, Klemann } \\
\text { and Martinec }\end{array}$ & Own & 0.52 & 5.9 & 120 & 4 & No & Yes & $\mathrm{PC}$ & (Sasgen et al. 2012) \\
\hline S\&S-1 & Spada and Stocchi & ICE-1 ${ }^{(4)}$ & 1 & 2 & 100 & 4 & No & No & SBL & SBL \\
\hline S\&S-3 & Spada and Stocchi & ICE-3G & 1 & 2 & 100 & 4 & No & No & SBL & SBL \\
\hline SVv-3-REF & $\begin{array}{l}\text { Schotman, Vermeersen } \\
\text { and van Hove }\end{array}$ & ICE-3G ${ }^{(5)}$ & 0.5 & 5 & 115 & 5 & No & No & SBL & SBL \\
\hline SVv-L-ALT & $\begin{array}{l}\text { Schotman, Vermeersen } \\
\text { and van Hove }\end{array}$ & Lambeck $^{(6)}$ & 1 & 1 & 98 & 5 & No & No & SBL & SBL \\
\hline$v d W-5$ & van der Wal & ICE-5G ${ }^{(7)}$ & 0.9 & 3.6 & 98 & 6 & No & No & $\mathrm{PC}$ & (van der Wal et al. 2011) \\
\hline $\mathrm{vdW}-5-\mathrm{R}$ & van der Wal & ICE-5G ${ }^{(7)}$ & 0.9 & 3.6 & 98 & 6 & No & Yes & $\mathrm{PC}$ & (van der Wal et al. 2011) \\
\hline $\mathrm{W} \& \mathrm{~W}-4$ & Wang and $\mathrm{Wu}$ & ICE-4G & 0.6 & $3-6$ & 115 & 5 & Yes & No & $\mathrm{PC}$ & (Wang and Wu 2006) \\
\hline$W \& W-5$ & Wang and $\mathrm{Wu}$ & ICE-5G ${ }^{(7)}$ & 0.6 & $3-6$ & 115 & 5 & Yes & No & $\mathrm{PC}$ & (Wang and Wu 2006) \\
\hline W\&O-EGOD & Wu and others & \multicolumn{7}{|c|}{ This model is estimated from geodetic Observations ${ }^{(8)}$} & $\mathrm{PC}$ & (Wu et al. 2010) \\
\hline
\end{tabular}

Note:

(1) This model was originally published by Paulson et al.(2007), and updated by Geruo A according to J. Wahr (private communication) who kindly provided the data.

(2) Modified from ICE-4G (Peltier 2002).

(3) As stated in Peltier (1994).

(4) Peltier and Andrews (1976).

(5) Modified from ICE-3G (Tushingham and Peltier 1991): glaciation included smoothing to fill in between discs of ice load.

(6) Lambeck et al. (1998) with modification.

(7) Version 1.2.

(8) The geoid-uplift relation of Wahr et al. (1995) is enforced for degrees 8 and above. However, SH coefficients of degrees 7 and below are estimated independently.

(9) Dziewonski and Anderson (1981)

(10) Currently, the SBL website is down and will be back with all the data later. At present, all data from this website can be downloaded from ftp://dutlru2. lr.tudelft.nl/pub/wouter/pgs.tar.gz.

al. 2010), no ice history or Earth parameter data are used in the computation.

\subsection{Long-Term Tide Gage Record}

Long-term tide gage records from 65 sites that are provided by the Permanent Service for Mean Sea Level (PSMSL) are used in this study. All the monthly averaged Revised Local Reference (RLR) records available from 1948 to 2010 are used to estimate sea-level trends. The Inverted Barometer (IB) correction is applied to all the tide gage records to remove the barotropic response of the ocean to the atmospheric pressure. Locations and time spans of these tide gages are shown in Table 2, tide gage derived trends without removing GIA effect are shown geographically in Fig. 1.

\subsection{Satellite Altimetry}

Multi-mission satellite radar altimetry observations are obtained from the AVISO DUACS V3.0 data product (Data Unification \& Altimeter Combination System, http://www. aviso.oceanobs.com). The gridded secular sea-level trends are then estimated by using weekly data products from 1992 to 2010. Corrections such as atmospheric (ionosphere, dry and wet troposphere) delays, ocean, solid Earth and polar tides, sea state bias and inverted barometer correction are applied to the data. The geographical variation of the sealevel trend over the Arctic and sub-Arctic Ocean is shown without removing GIA contribution (Fig. 2). We select the region inside the red polygon as our study region. That is primarily because that in this region we have steric-corrected altimetry result available to us in order to compare with ocean mass component of sea-level change derived from 
Table 2. 65 selected tide gage sites in this study.

\begin{tabular}{|c|c|c|c|c|}
\hline Tide Gage Name & Latitude $\left({ }^{\circ} \mathbf{N}\right)$ & Longitude $\left({ }^{\circ} \mathbf{E}\right)$ & Data Span & $\begin{array}{l}\text { Data Length } \\
\text { (Months) }\end{array}$ \\
\hline NY-ALESUND & 78.933 & 11.933 & $1976-2010$ & 355 \\
\hline BARENTSBURG & 78.067 & 14.250 & $1948-2010$ & 704 \\
\hline BODO & 67.283 & 14.383 & $1949-2010$ & 639 \\
\hline KABELVAG & 68.217 & 14.483 & $1948-2010$ & 739 \\
\hline ANDENES & 69.317 & 16.150 & $1948-2010$ & 413 \\
\hline EVENSKJAER & 68.583 & 16.550 & $1948-1970$ & 255 \\
\hline HARSTAD & 68.800 & 16.550 & $1952-2010$ & 670 \\
\hline NARVIK & 68.433 & 17.417 & $1948-2010$ & 744 \\
\hline TROMSO & 69.650 & 18.967 & $1952-2010$ & 694 \\
\hline HAMMERFEST & 70.667 & 23.667 & $1957-2010$ & 577 \\
\hline HONNINGSVAG & 70.983 & 25.983 & $1970-2010$ & 464 \\
\hline VARDO & 70.333 & 31.100 & $1948-2010$ & 488 \\
\hline MYS PIKSHUEVA & 69.550 & 32.433 & $1955-1990$ & 361 \\
\hline MURMANSK & 68.967 & 33.050 & $1952-2010$ & 694 \\
\hline POLYARNIY & 69.200 & 33.483 & $1948-1990$ & 515 \\
\hline TERIBERKA & 69.200 & 35.117 & $1949-1990$ & 494 \\
\hline MALYE KARMAKULY & 72.367 & 52.700 & $1950-2000$ & 402 \\
\hline KRENKELIA & 80.617 & 58.050 & $1962-1991$ & 343 \\
\hline BOLVANSKII NOS & 70.450 & 59.083 & $1951-1993$ & 514 \\
\hline BELYI NOS & 69.600 & 60.217 & $1957-1980$ & 277 \\
\hline UGORSKII SHAR & 69.817 & 60.750 & $1950-1989$ & 480 \\
\hline AMDERMA & 69.750 & 61.700 & $1950-2009$ & 707 \\
\hline RUSSKAIA GAVAN II & 76.183 & 62.583 & $1953-1993$ & 474 \\
\hline UST KARA & 69.250 & 64.517 & $1950-2009$ & 622 \\
\hline MORZHOVAIA & 71.417 & 67.583 & $1954-1994$ & 480 \\
\hline ZHELANIA II & 76.950 & 68.550 & $1951-1996$ & 529 \\
\hline SE-LAHA & 70.150 & 72.567 & $1967-1992$ & 279 \\
\hline TADIBE-IAHA & 70.367 & 72.567 & $1955-1989$ & 420 \\
\hline VISE & 79.500 & 76.983 & $1953-2009$ & 664 \\
\hline DIKSON & 73.500 & 80.400 & $1950-1997$ & 559 \\
\hline UEDINENIA & 77.500 & 82.200 & $1953-1995$ & 502 \\
\hline SOPOCHNAIA KARGA & 71.867 & 82.700 & $1958-2009$ & 590 \\
\hline IZVESTIA TSIK & 75.950 & 82.950 & $1954-2009$ & 672 \\
\hline STERLEGOVA & 75.417 & 88.900 & $1950-1995$ & 533 \\
\hline ISACHENKO & 77.150 & 89.200 & $1954-1993$ & 471 \\
\hline GOLOMIANYI & 79.550 & 90.617 & $1954-2009$ & 656 \\
\hline PRAVDY & 76.267 & 94.767 & $1950-1994$ & 537 \\
\hline RUSSKII & 77.167 & 96.433 & $1951-1989$ & 435 \\
\hline KRASNOFLOTSKIE & 78.600 & 98.833 & $1954-1987$ & 408 \\
\hline GEIBERGA & 77.600 & 101.517 & $1951-1995$ & 524 \\
\hline PESCHANYI & 79.433 & 102.483 & $1962-1993$ & 374 \\
\hline SOLNECHNAIA & 78.200 & 103.267 & $1951-1989$ & 468 \\
\hline FEDOROVA & 77.717 & 104.300 & $1950-2000$ & 493 \\
\hline MALYI TAIMYR & 78.083 & 106.817 & $1950-1991$ & 504 \\
\hline ANDREIA & 76.800 & 110.750 & $1951-1999$ & 544 \\
\hline
\end{tabular}


Table 2. (Continued)

\begin{tabular}{lcccc}
\hline \multicolumn{1}{c}{ Tide Gage Name } & Latitude $\left({ }^{\circ} \mathbf{N}\right)$ & Longitude $\left({ }^{\circ} \mathbf{E}\right)$ & Data Span & $\begin{array}{c}\text { Data Length } \\
\text { (Months) }\end{array}$ \\
\hline PREOBRAZHENIA & 74.667 & 112.933 & $1951-1989$ & 468 \\
TERPIAI-TUMSA & 73.550 & 118.667 & $1956-1998$ & 496 \\
UST OLENEK & 73.000 & 119.867 & $1950-1998$ & 389 \\
DUNAI & 73.933 & 124.500 & $1951-2009$ & 701 \\
TIKSI & 71.583 & 128.917 & $1949-2009$ & 732 \\
MUOSTAH & 71.550 & 130.033 & $1951-1995$ & 538 \\
KOTELNYI & 76.000 & 137.867 & $1951-2009$ & 702 \\
SANNIKOVA & 74.667 & 138.900 & $1950-2009$ & 706 \\
KIGILIAH & 73.333 & 139.867 & $1951-2009$ & 705 \\
SVIATOI NOS & 72.833 & 140.733 & $1951-1987$ & 444 \\
ZEMLIA BUNGE & 74.883 & 142.117 & $1951-1987$ & 444 \\
SHALAUROVA & 73.183 & 143.233 & $1950-2001$ & 605 \\
ZHOHOVA & 76.150 & 152.833 & $1959-1993$ & 404 \\
AMBARCHIK & 69.617 & 162.300 & $1950-2009$ & 600 \\
CHETYREHSTOLBOVOI & 70.633 & 162.483 & $1951-1994$ & 519 \\
RAU-CHUA & 69.500 & 166.583 & $1950-2009$ & 590 \\
AION & 69.933 & 167.983 & $1954-2007$ & 576 \\
PEVEK & 69.700 & 170.250 & $1950-2009$ & 671 \\
VALKARKAI & 70.083 & 170.933 & $1956-1993$ & 439 \\
BILLINGA & 69.883 & 175.767 & $1953-1995$ & 511 \\
\hline
\end{tabular}

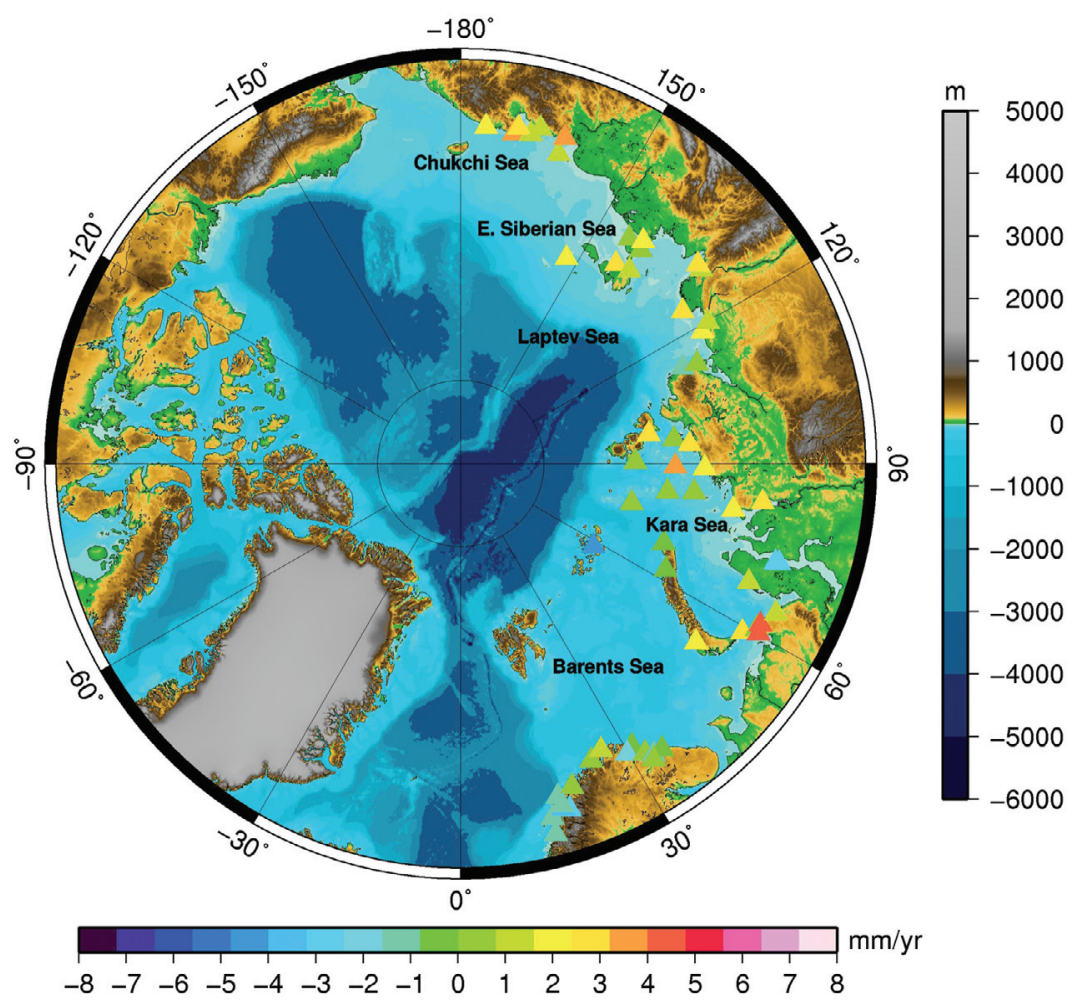

Fig. 1. Geographical locations of tide gage sites used in this study, color-coded triangles indicate the tide gage locations with their respective estimated sea-level trend (without removing GIA effect). Background: Bathymetric data from Jakobsson et al. (2008). 
GRACE. The averaged satellite altimetry observed sealevel trend over the study region is $1.90 \mathrm{~mm} \mathrm{yr}^{-1}$ without removing both GIA effect and the steric effect. The steric component is removed from the altimetry observation using an updated steric product from Ishii et al. (2006) following the same procedure described in Kuo et al. (2008).

\subsection{GRACE}

The data we used here are 96 GRACE RL04 monthly spherical harmonic gravity models generated by the Center for Space Research (CSR), University of Texas at Austin, spanning from January 2003 to December 2010. Spherical harmonic coefficients are provided up to a maximum degree 60. C20 derived from Satellite Laser Ranging (SLR) observation are used to replace the C20 in GRACE monthly solutions. Decorrelation and leakage reduction are conducted according to Duan et al (2009) and Guo et al (2010), $300 \mathrm{~km}$ half width Gaussian filter is used in here. An estimated ocean bottom pressure trend after decorrelation is plotted in Fig. 3, GIA contribution is not removed yet and also the leakage reduction is not conducted yet because it needs to remove the GIA effect first. In our final result, we first remove the GIA contribution using each of the available model, then apply the leakage reduction.

\section{COMPARISON RESULTS}

The comparison between the GIA models are studied in Guo et al. (2012) by using two approximate relationships developed by Wahr (Wahr et al. 1995), results show unacceptable differences between those models when they are used in the GRACE study. In this study we focus on the Arctic Ocean and compare the differences when they are used to remove GIA contribution from contemporary geodetic observations. First, we will compare those model predictions over the entire Arctic Ocean, and then we will select a study region (the Arctic Ocean inside the red boundary) where all three measurements are available.

\subsection{Tide Gage}

Figure 4 shows the GIA model prediction for tide gage observation over the entire Arctic Ocean from 13 GIA models with tide gage sites used in this study plotted as magenta dots. In Barents Sea and Kara Sea, almost every model show similar patterns except S\&S-1 and SVv-L-ALT, the reason might come from the different ICE history model they used. The same reason for the East Siberian Sea, GIA models using ICE3G and ICE4G show negative values, that is because in ICE3G and ICE4G, East Siberian area are assumed to have thick ice sheets covered before. The location of large negative trend in Barents Sea in W\&O-EGOD model is different with others, we mentioned that this model is an esti-

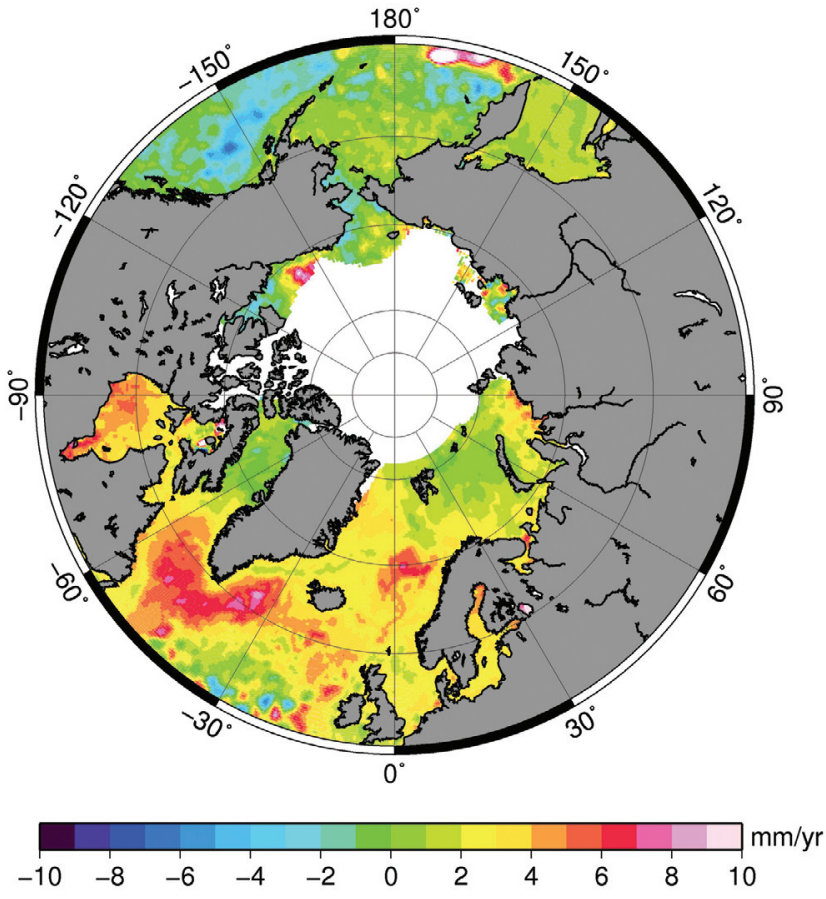

Fig. 2. Secular sea-level trend estimated from AVISO multi-mission radar altimetry data product (without removing GIA effect).

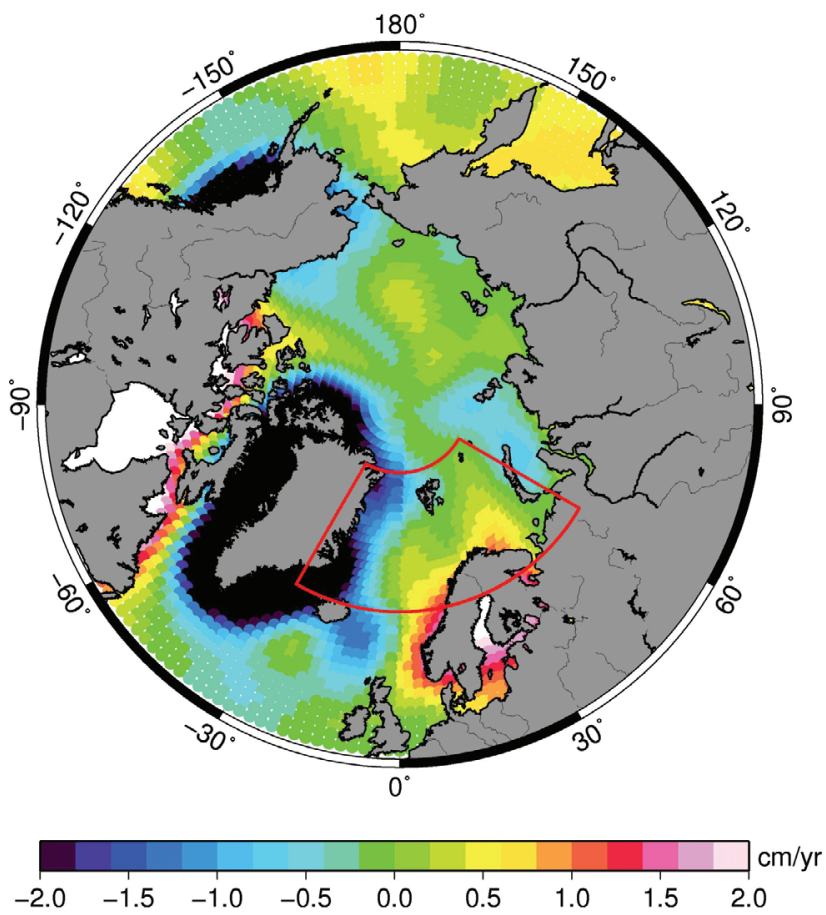

Fig. 3. GRACE-derived ocean bottom pressure trend without removing GIA effect, leakage reduction is not conducted before removing GIA effect. CSR Level-2 RL04 monthly gravity models are used from January 2003 to December 2010. Red polygon denotes the study region wherein the GRACE result is compared with steric-corrected altimetry sea-level change. 

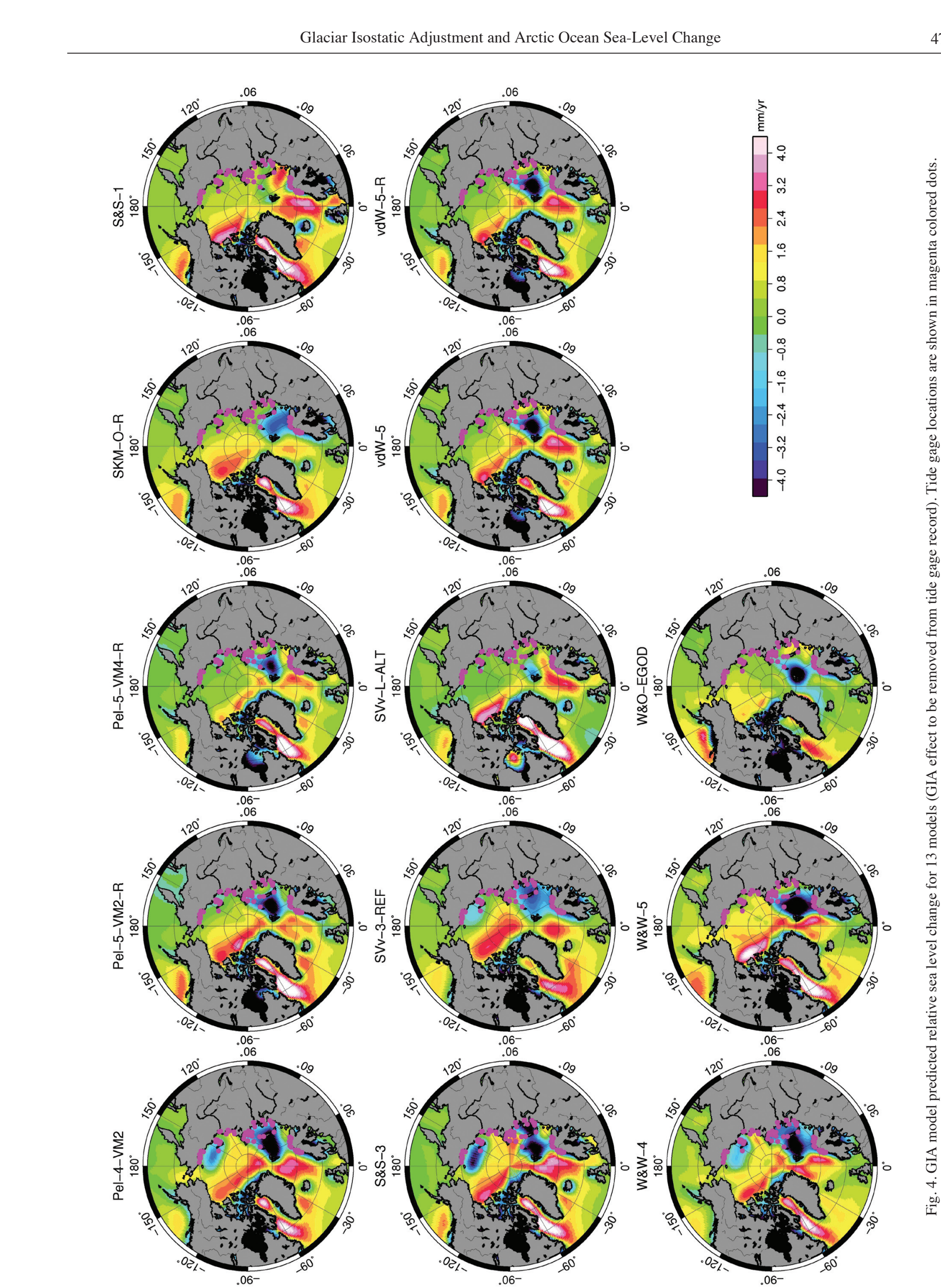
mate from geodetic observations, the decreasing ice cover in Svalbard Island is already considered in their inversion, but it is not included in other GIA models. If averaged over the entire Arctic Ocean, the range of GIA correction for the tide gage is from -0.26 to $0.81 \mathrm{~mm} \mathrm{yr}^{-1}$ (Table 3).

In this study, we use 65 tide gage sites along the coasts of the Barents, Kara, Laptev and East Siberian Seas, and remove GIA contribution using models to obtain the climate related regional secular sea-level change. Simply averaging all the obtained sea-level trends from tide gages without removing GIA effect gives a rate of sea-level trend of $0.90 \pm 0.43 \mathrm{~mm} \mathrm{yr}^{-1}$, after removing GIA effect, the number increases to $1.72 \pm 0.44 \mathrm{~mm} \mathrm{yr}^{-1}$, which is consistent with Proshutinsky et al. (2004) who use long-term (1954 - 1989) tide gages to estimate a rate of sea-level rise of $1.85 \mathrm{~mm} \mathrm{yr}^{-1}$. All that information taken from tide gage sites and GIA models in this study are given in Table 4. In addition, the sea-level trends with and without removing GIA effect from 65 selected tide gage sites are plotted along the longitude in Fig. 5, the grey belt in Fig. 5 indicates the uncertainty of applied GIA corrections, and one could easily recognize the
Table 3. Statistics of GIA contribution over the entire Arctic Ocean: 66 to $90^{\circ} \mathrm{N}$ (unit: $\mathrm{mm} \mathrm{yr}^{-1}$ ). Abbreviations: GIA - GIA Contribution; TG Tide Gage; RA - Radar Altimetry; STD - Standard Deviation.

\begin{tabular}{l|c|c|c}
\hline \multicolumn{1}{c|}{ Model } & GIA $_{\text {TG }}$ & GIA $_{\text {RA }}$ & GIA $_{\text {GRACE }}$ \\
\hline Pel-4-VM2 & 0.18 & 0.07 & 0.82 \\
Pel-5-VM2-R & 0.31 & -0.06 & -0.63 \\
Pel-5-VM4-R & 0.08 & -0.01 & 0.35 \\
SKM-O-R & 0.11 & -0.24 & -5.76 \\
S\&S-1 & 0.81 & -0.07 & -2.63 \\
S\&S-3 & 0.23 & -0.05 & 0.09 \\
SVv-3-REF & 0.46 & -0.13 & -1.53 \\
SVv-L-ALT & 0.20 & -0.05 & 0.25 \\
vdW-5 & 0.25 & -0.05 & -0.39 \\
vdW-5-R & 0.10 & -0.08 & -0.42 \\
W\&O-EGOD & -0.26 & 0.11 & 1.31 \\
W\&W-4 & 0.08 & 0.01 & 0.86 \\
W\&W-5 & 0.37 & -0.09 & -0.77 \\
Pau-5-R & & & -0.68 \\
\hline MEAN \& STD & $0.22 \pm 0.25$ & $-0.05 \pm 0.09$ & $-0.65 \pm 1.79$ \\
\hline
\end{tabular}

Table 4. Statistics of the sea-level trends from 65 selected tide gage sites in this study (unit: $\mathrm{mm} \mathrm{yr}^{-1}$ ). Abbreviations: MEAN - Mean value; STD - Standard deviation; $\mathrm{RSL}_{\mathrm{TG}}$ - Tide gage recorded sea-level trend; $\mathrm{GIA}_{\mathrm{TG}}$ - GIA contribution to tide gage observation; $\mathrm{RSL}_{\mathrm{COR}}$ - Tide gage relative sea-level trend after removing GIA effect.

\begin{tabular}{|c|c|c|c|c|c|c|c|}
\hline TIDE GAGE & $\begin{array}{l}\text { DATA Length } \\
\text { (Months) }\end{array}$ & $\mathbf{R S L}_{\mathrm{TG}}^{\mathrm{MEAN}}$ & $\mathbf{R S L}_{\mathrm{TG}}^{\mathrm{STD}}$ & GIA $\mathbf{A}_{\mathrm{TG}}^{\mathrm{MEAN}}$ & $\mathbf{G I A}_{\mathrm{TG}}^{\mathrm{STD}}$ & $\mathbf{R S L}_{\mathrm{COR}}^{\mathrm{MEAN}}$ & $\mathbf{R S L}_{\mathrm{COR}}^{\mathrm{STD}}$ \\
\hline NY-ALESUND & 355 & -3.98 & 0.19 & -0.64 & 1.28 & -3.34 & 1.28 \\
\hline BARENTSBURG & 704 & -3.05 & 0.13 & -1.22 & 1.42 & -1.83 & 1.42 \\
\hline BODO & 639 & -1.41 & 0.16 & -2.37 & 1.00 & 0.96 & 1.00 \\
\hline KABELVAG & 739 & -1.15 & 0.14 & -1.15 & 0.93 & 0.01 & 0.93 \\
\hline ANDENES & 413 & -1.30 & 0.17 & -0.67 & 0.92 & -0.63 & 0.92 \\
\hline EVENSKJAER & 255 & -4.86 & 0.59 & -1.97 & 0.96 & -2.89 & 0.96 \\
\hline HARSTAD & 670 & -1.15 & 0.12 & -1.65 & 0.94 & 0.50 & 0.94 \\
\hline NARVIK & 744 & -2.61 & 0.14 & -2.72 & 1.01 & 0.11 & 1.01 \\
\hline TROMSO & 694 & -0.13 & 0.13 & -1.68 & 1.02 & 1.55 & 1.02 \\
\hline HAMMERFEST & 577 & 0.51 & 0.15 & -1.87 & 1.26 & 2.38 & 1.26 \\
\hline HONNINGSVAG & 464 & 1.44 & 0.21 & -1.92 & 1.31 & 3.36 & 1.31 \\
\hline VARDO & 488 & -0.37 & 0.13 & -2.02 & 1.35 & 1.64 & 1.35 \\
\hline MYS PIKSHUEVA & 361 & -0.03 & 0.29 & -2.33 & 1.26 & 2.29 & 1.26 \\
\hline MURMANSK & 694 & 3.28 & 0.19 & -2.72 & 1.15 & 6.00 & 1.15 \\
\hline POLYARNIY & 515 & -1.81 & 0.20 & -2.32 & 1.24 & 0.51 & 1.24 \\
\hline TERIBERKA & 494 & 0.00 & 0.26 & -1.69 & 1.35 & 1.69 & 1.35 \\
\hline MALYE KARMAKULY & 402 & 2.11 & 0.48 & -1.69 & 1.59 & 3.80 & 1.59 \\
\hline KRENKELIA & 343 & -4.90 & 0.35 & -1.73 & 0.94 & -3.17 & 0.94 \\
\hline BOLVANSKII NOS & 514 & 2.53 & 0.29 & -0.86 & 1.49 & 3.39 & 1.49 \\
\hline BELYI NOS & 277 & 4.36 & 1.28 & -0.62 & 1.31 & 4.98 & 1.31 \\
\hline UGORSKII SHAR & 480 & 0.45 & 0.30 & -0.68 & 1.41 & 1.14 & 1.41 \\
\hline AMDERMA & 707 & 3.92 & 0.18 & -0.67 & 1.45 & 4.59 & 1.45 \\
\hline
\end{tabular}


Table 4. (Continued)

\begin{tabular}{|c|c|c|c|c|c|c|c|}
\hline TIDE GAGE & $\begin{array}{l}\text { DATA Length } \\
\text { (Months) }\end{array}$ & $\mathbf{R S L}_{\mathrm{TG}}^{\mathrm{MEAN}}$ & $\mathbf{R S L}_{\mathrm{TG}}^{\mathrm{STD}}$ & $\mathbf{G I A}_{\mathrm{TG}}^{\mathrm{MEAN}}$ & $\mathbf{G I A}_{\mathrm{TG}}^{\mathrm{STD}}$ & $\mathbf{R S L}_{\mathrm{COR}}^{\mathrm{MEAN}}$ & $\mathbf{R S L}_{\mathrm{COR}}^{\mathrm{STD}}$ \\
\hline RUSSKAIA GAVAN II & 474 & -0.86 & 0.28 & -2.07 & 1.43 & 1.20 & 1.43 \\
\hline UST KARA & 622 & 1.48 & 0.26 & -0.60 & 1.40 & 2.08 & 1.40 \\
\hline MORZHOVAIA & 480 & 0.65 & 0.52 & -0.66 & 1.97 & 1.31 & 1.97 \\
\hline ZHELANIA II & 529 & -0.96 & 0.28 & -1.43 & 1.27 & 0.48 & 1.27 \\
\hline SE-LAHA & 279 & -2.62 & 1.16 & -0.58 & 1.34 & -2.04 & 1.34 \\
\hline TADIBE-IAHA & 420 & -3.14 & 0.74 & -0.58 & 1.40 & -2.56 & 1.40 \\
\hline VISE & 664 & 0.00 & 0.18 & -1.00 & 1.58 & 1.00 & 1.58 \\
\hline DIKSON & 559 & 1.57 & 0.39 & -0.50 & 1.33 & 2.06 & 1.33 \\
\hline UEDINENIA & 502 & 0.34 & 0.30 & -0.88 & 1.36 & 1.22 & 1.36 \\
\hline SOPOCHNAIA KARGA & 590 & 2.53 & 0.53 & -0.70 & 1.15 & 3.23 & 1.15 \\
\hline IZVESTIA TSIK & 672 & -0.18 & 0.18 & -0.65 & 1.04 & 0.47 & 1.04 \\
\hline STERLEGOVA & 533 & 1.77 & 0.38 & -0.74 & 0.92 & 2.51 & 0.92 \\
\hline ISACHENKO & 471 & 2.90 & 0.31 & -0.87 & 1.13 & 3.77 & 1.13 \\
\hline GOLOMIANYI & 656 & 0.38 & 0.17 & -0.49 & 1.18 & 0.87 & 1.18 \\
\hline PRAVDY & 537 & 2.29 & 0.39 & -0.82 & 0.86 & 3.11 & 0.86 \\
\hline RUSSKII & 435 & 0.54 & 0.41 & -0.77 & 0.88 & 1.31 & 0.88 \\
\hline KRASNOFLOTSKIE & 408 & 2.47 & 0.40 & -0.37 & 0.84 & 2.85 & 0.84 \\
\hline GEIBERGA & 524 & 2.20 & 0.24 & -0.42 & 0.68 & 2.62 & 0.68 \\
\hline PESCHANYI & 374 & 3.44 & 0.44 & 0.12 & 0.56 & 3.32 & 0.56 \\
\hline SOLNECHNAIA & 468 & 4.44 & 0.30 & -0.14 & 0.61 & 4.58 & 0.61 \\
\hline FEDOROVA & 493 & 1.84 & 0.30 & -0.16 & 0.56 & 2.00 & 0.56 \\
\hline MALYI TAIMYR & 504 & 2.36 & 0.22 & 0.12 & 0.47 & 2.24 & 0.47 \\
\hline ANDREIA & 544 & 3.34 & 0.29 & 0.18 & 0.41 & 3.16 & 0.41 \\
\hline PREOBRAZHENIA & 468 & 0.13 & 0.37 & 0.01 & 0.36 & 0.12 & 0.36 \\
\hline TERPIAI-TUMSA & 496 & 1.82 & 0.39 & 0.09 & 0.46 & 1.73 & 0.46 \\
\hline UST OLENEK & 389 & 0.85 & 1.32 & 0.04 & 0.43 & 0.81 & 0.43 \\
\hline DUNAI & 701 & 2.26 & 0.28 & 0.15 & 0.47 & 2.11 & 0.47 \\
\hline TIKSI & 732 & 1.37 & 0.24 & -0.15 & 0.24 & 1.52 & 0.24 \\
\hline MUOSTAH & 538 & 2.65 & 0.46 & -0.16 & 0.23 & 2.81 & 0.23 \\
\hline KOTELNYI & 702 & 4.92 & 0.26 & -0.26 & 0.55 & 5.17 & 0.55 \\
\hline SANNIKOVA & 706 & 1.33 & 0.25 & -0.48 & 0.72 & 1.81 & 0.72 \\
\hline KIGILIAH & 705 & 0.43 & 0.22 & -0.52 & 0.64 & 0.95 & 0.64 \\
\hline SVIATOI NOS & 444 & 2.63 & 0.53 & -0.50 & 0.56 & 3.13 & 0.56 \\
\hline ZEMLIA BUNGE & 444 & 3.43 & 0.41 & -0.59 & 0.85 & 4.02 & 0.85 \\
\hline SHALAUROVA & 605 & 0.56 & 0.29 & -0.59 & 0.68 & 1.15 & 0.68 \\
\hline ZHOHOVA & 404 & 2.09 & 0.47 & -0.47 & 0.99 & 2.56 & 0.99 \\
\hline AMBARCHIK & 600 & 3.51 & 0.39 & -0.16 & 0.30 & 3.67 & 0.30 \\
\hline CHETYREHSTOLBOVOI & 519 & 1.46 & 0.47 & -0.21 & 0.35 & 1.68 & 0.35 \\
\hline RAU-CHUA & 590 & 0.96 & 0.37 & -0.16 & 0.27 & 1.12 & 0.27 \\
\hline AION & 576 & 0.97 & 0.37 & -0.14 & 0.31 & 1.11 & 0.31 \\
\hline PEVEK & 671 & 3.12 & 0.27 & -0.15 & 0.27 & 3.27 & 0.27 \\
\hline VALKARKAI & 439 & 3.31 & 0.54 & -0.15 & 0.31 & 3.46 & 0.31 \\
\hline BILLINGA & 511 & 1.85 & 0.44 & -0.09 & 0.30 & 1.94 & 0.30 \\
\hline MEAN \& STD & 530.88 & 0.90 & 0.43 & -0.83 & 0.44 & 1.72 & 0.44 \\
\hline
\end{tabular}


Effect of GIA Process on the Sea-Level Trends Estimated from Long-term Sub-Arctic Tide Gages

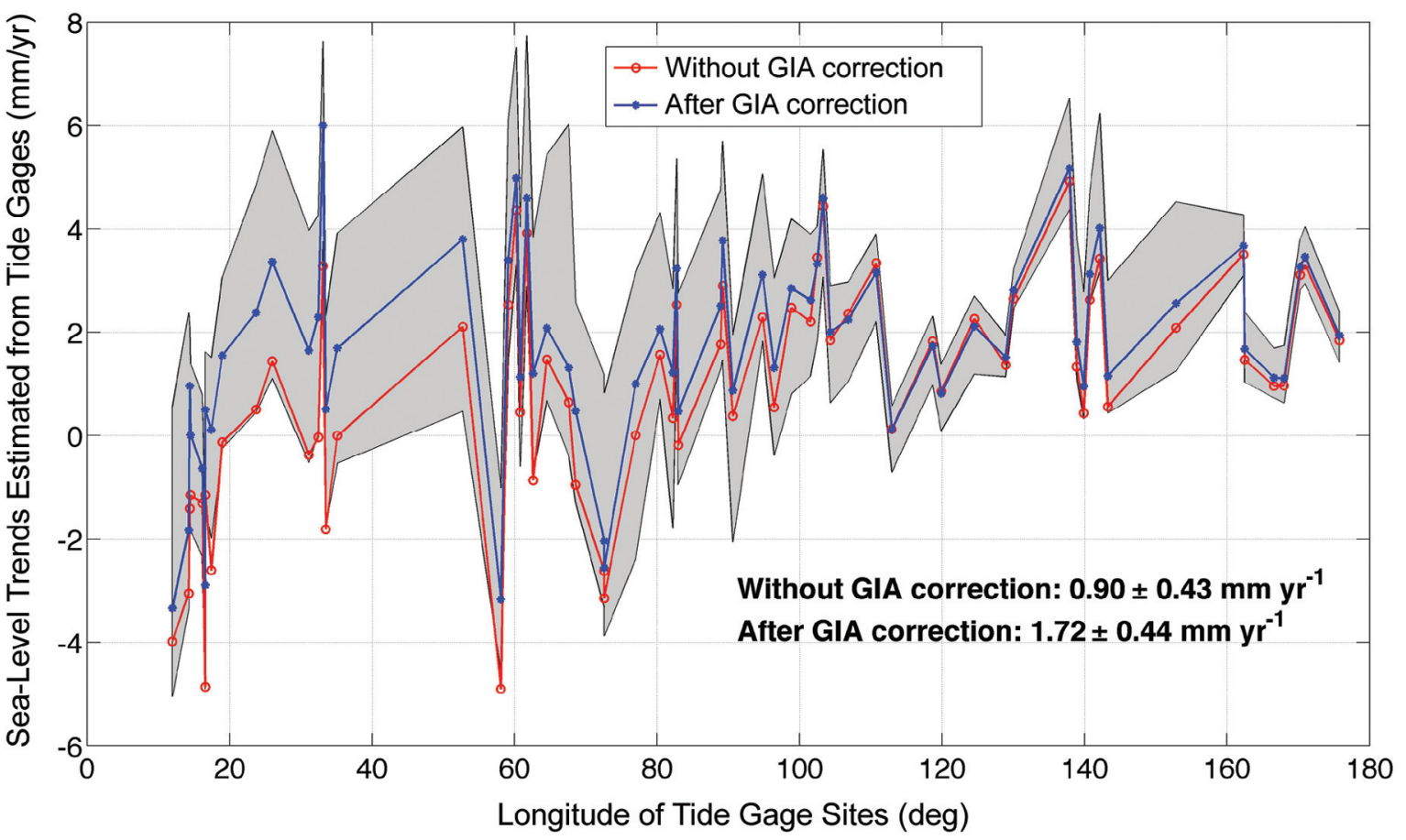

Fig. 5. Sea-level trends estimated from 65 selected tide gage sites with and without removing GIA contribution, red line indicates tide gage sea-level trends without GIA correction, blue line indicates the MEAN value of corrected tide gage recorded sea level trends for each site, while grey belt indicates the range of 13 GIA models.

large uncertainty exists between 20 to $60^{\circ} \mathrm{E}$ where the GIA signal is obvious and also the region between 140 to $160^{\circ} \mathrm{E}$ that is probably due to the difference of ICE history models used in their GIA modelling (Fig. 4).

In our study, we also compare tide gage derived sealevel change to altimeter derived sea-level change after removing the GIA effect. Here the steric component is not removed from altimetry observations, since it is also equally present in tide gage observations. Results from 10 sites (Names in bold in Table 2) that have same time span from 1992 to 2010 are used. They are all located along the coast of the Barents Sea. An Inverted Barometer (IB) correction is applied to all the tide gage sites in order to compare with the altimeter derived sea-level trends. Instead of comparing the time series of sea-level change obtained from both tide gage and radar altimetry for each tide gage location, here comparison is made after directly averaging all the measurements over study region because we are interested in the role of GIA when correcting both measurements. The sea-level trend without removing GIA effect is $0.15 \pm 0.65 \mathrm{~mm} \mathrm{yr}^{-1}$, after removing GIA effect, is $2.02 \pm 1.02 \mathrm{~mm} \mathrm{yr}^{-1}$. The tide gage NY-ALESUND in Svalbard Island, which has data record from 1992 to 2010, is not included because it is highly influenced by the elastic loading from the present day ice melting.

\subsection{Altimetry}

Figure 6 shows the GIA model prediction of sea surface change observed by altimetry over the Arctic Ocean by using 13 GIA models available to us. In Barents Sea, Pel5-VM2-R and Pel-5-VM4-R show significant difference with other models. For the models with rotational feedback, Pel-5-VM2-R and Pel-5-VM4-R show larger negative values than SKM-O-R and vdW-5-R in the oceans of western hemisphere. The others models show similar patterns. Figure 7 shows the altimetry derived sea-level trend after removing GIA contribution. If averaged over the entire Arctic Ocean, the range of GIA contribution to altimeter-observed is from -0.24 to $0.11 \mathrm{~mm} \mathrm{yr}^{-1}$ (Table 3), which represents a large range that directly contributes to the error in the estimated sea-level trend.

Here we compare the tide gage derived and the altimetry derived sea-level trend after GIA corrections to both data sets during 1992 to 2010. Since tide gage records are just point values of regional sea-level change, here altimeter derived sea-level trend is averaged near the 10 selected tide gages assuming that sea-level variation in these areas is insignificant as compared to sea level change. The sea-level trend without removing GIA effect from altimeter measurement is $2.88 \mathrm{~mm} \mathrm{yr}^{-1}$, and after removing GIA effect, this 



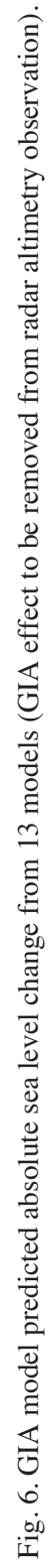
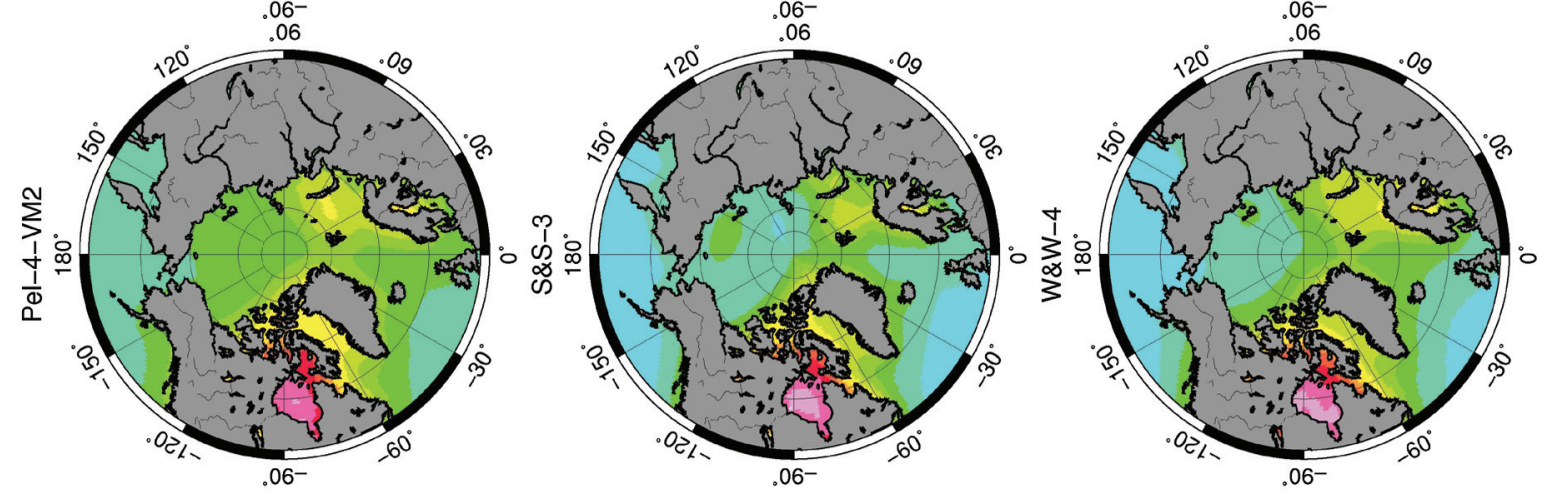

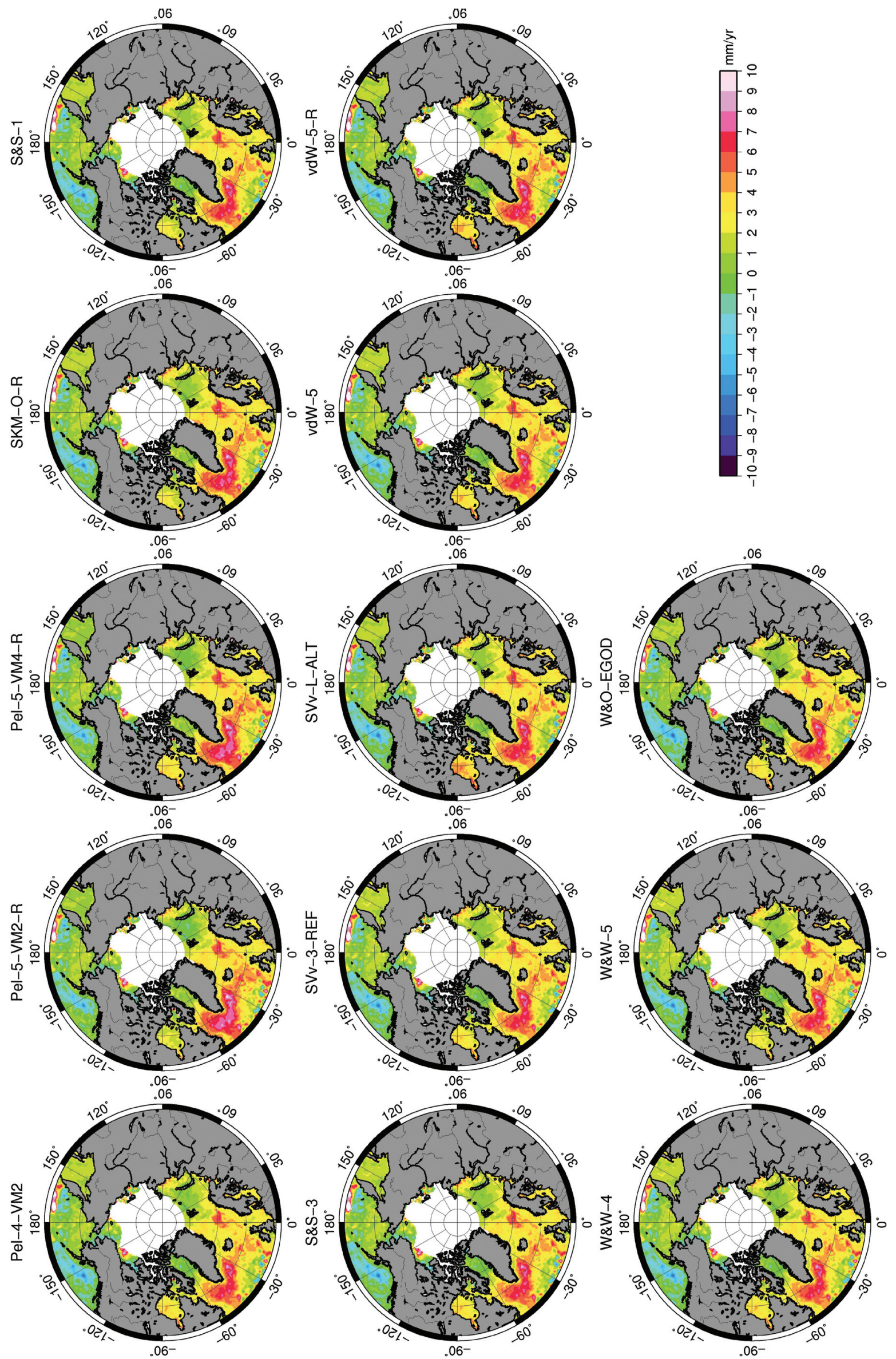
number is $2.73 \pm 0.11 \mathrm{~mm} \mathrm{yr}^{-1}$ (Table 5). From Table 5, one could easily tell that GIA plays a large role in tide gage derived sea-level trend than altimeter.

\subsection{GRACE}

Figure 8 shows the GRACE-Type mass change contribution computed from 14 contemporary GIA models. It shows significant difference between these models. When averaging over the entire Arctic Ocean, the range of GIA contribution is from -5.76 to $1.31 \mathrm{~mm} \mathrm{yr}^{-1}$ (See details in Table 3), which is practically the same magnitude as the GRACE-derived ocean bottom pressure trend estimation

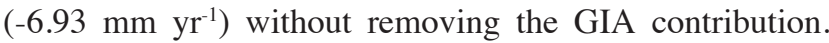
Large negative values were found in SKM-O-R model with unknown cause. Models use same or similar ICE history models or viscosity models show similar patterns, like Pel4-VM2 and W\&W-4, Pel-5-VM2-R and Pel-5-VM4-R. But the uncertainties are still large enough to make the GRACEderived result unreliable in this study region. Figure 9 shows the GRACE derived ocean bottom pressure after removing GIA contribution. Significant differences exist between those models. The most common GIA models used right now in GRACE community are Pau-5-R and Pel-5-VM2$\mathrm{R}$, however they are shown significantly different in both spatial pattern and amplitude even though they are using the same ICE history models and similar viscosity models.

In our study, we also try to compare steric-corrected altimetry derived ocean mass component over the study region. The steric component, which comes from the ocean water density change resulting from changes in salinity and temperature, is removed from the altimeter measurement. The ocean mass component from steric-corrected altimeter

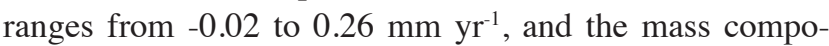
nent from GRACE observation after removing GIA effect is ranging from -7.84 to $1.18 \mathrm{~mm} \mathrm{yr}^{-1}$. The reason why they do not agree is the primarily large range of uncertainty in GIA contribution over the study region, or the errors in Arctic Ocean altimetry or steric measurements, or all of the above.

From our study, we know that GIA contribution for satellite altimetry measured sea-level change is an order of magnitude smaller than contributions for tide gage measured sea-level changes and GRACE measured surface mass changes. Hence, uncertainties in GIA models have less influence on altimetry measured sea-level changes than the other two. Higher sensitivity of GRACE measured surface mass changes to GIA may be due to the fact that rock density is about 3 times of that of water, since in GIA, crustal uplift and RSL change have practically the same magnitude with opposite signs, while satellite altimetry measures the sum of crustal uplift and RSL change. This also explains why tide gage measured relative sea level change is more sensitive to GIA than altimetry measured absolute sea level change.
Based on our comparison, SKM-O-R provides the appropriate GIA corrections over our study region, if consistence between GRACE and altimetry results of sea-level is taken as criteria. However, due to the unacceptably large discrepancies among the GIA models we have compared (e.g., Guo et al. 2012), there is no evident reason to conclude that one specific GIA model is better than the others. We wonder whether the better fit as indicated by the SKMO-R model for our study region could just be a coincidence, and that a different model may be a better fit for a different region. We conclude that it is difficult to identify the best GIA model to be recommended for the Arctic Ocean region for sea-level studies.

\section{CONCLUDING REMARKS}

The effects of GIA to geodetic observations to study present-day sea-level change over the Arctic Ocean have been investigated, and the differences between those model predictions are described and compared. The conclusions are as follows.

(1) GIA contribution for tide gage measurements over the Arctic Ocean has a large range when using different GIA models, this study indicates that this value is ranged from -0.26 to $0.81 \mathrm{~mm} \mathrm{yr}^{-1}$. Sea-level trends from $65 \mathrm{se}-$ lected long-term tide gages along the coast of the Arctic Ocean are obtained, after GIA corrections, the estimated sea-level trend is $1.72 \pm 0.44 \mathrm{~mm} \mathrm{yr}^{-1}$, which is consistent with a previous study (Proshutinsky et al. 2004), who used Pel-5-VM2-R for GIA correction.

Table 5: Comparison of the sea-level trends derived from both tide gage and radar altimetry after removing GIA effect (unit: $\mathrm{mm} \mathrm{yr}^{-1}$ ). Abbreviations: GIA - GIA contribution; TG - Tide Gage; SL - SeaLevel trend; RA - Radar Altimetry.

\begin{tabular}{l|c|c|c|c}
\hline \multicolumn{1}{c|}{ Model } & GIA $_{\text {TG }}$ & SL $_{\mathbf{T G}}$ & $\mathbf{G I A}_{\mathbf{R A}}$ & $\mathbf{S L}_{\mathbf{R A}}$ \\
\hline Pel-4-VM2 & -1.74 & 1.89 & 0.22 & 2.66 \\
Pel-5-VM2-R & -1.32 & 1.46 & 0.32 & 2.56 \\
Pel-5-VM4-R & 0.05 & 0.10 & 0.13 & 2.75 \\
SKM-O-R & -2.79 & 2.93 & 0.05 & 2.83 \\
S\&S-1 & -1.93 & 2.08 & 0.16 & 2.72 \\
S\&S-3 & -2.22 & 2.37 & 0.14 & 2.74 \\
SVv-3-REF & -2.84 & 2.99 & 0.15 & 2.73 \\
SVv-L-ALT & -0.58 & 0.73 & -0.08 & 2.96 \\
vdW-5 & -1.18 & 1.33 & 0.06 & 2.82 \\
vdW-5-R & -1.11 & 1.26 & 0.08 & 2.80 \\
W\&O-EGOD & -2.34 & 2.48 & 0.29 & 2.59 \\
W\&W-4 & -3.05 & 3.20 & 0.27 & 2.61 \\
W\&W-5 & -3.35 & 3.49 & 0.20 & 2.68 \\
\hline MEAN \& STD & $-1.88 \pm 1.02$ & $2.02 \pm 1.02$ & $0.15 \pm 0.11$ & $2.73 \pm 0.11$ \\
\hline
\end{tabular}



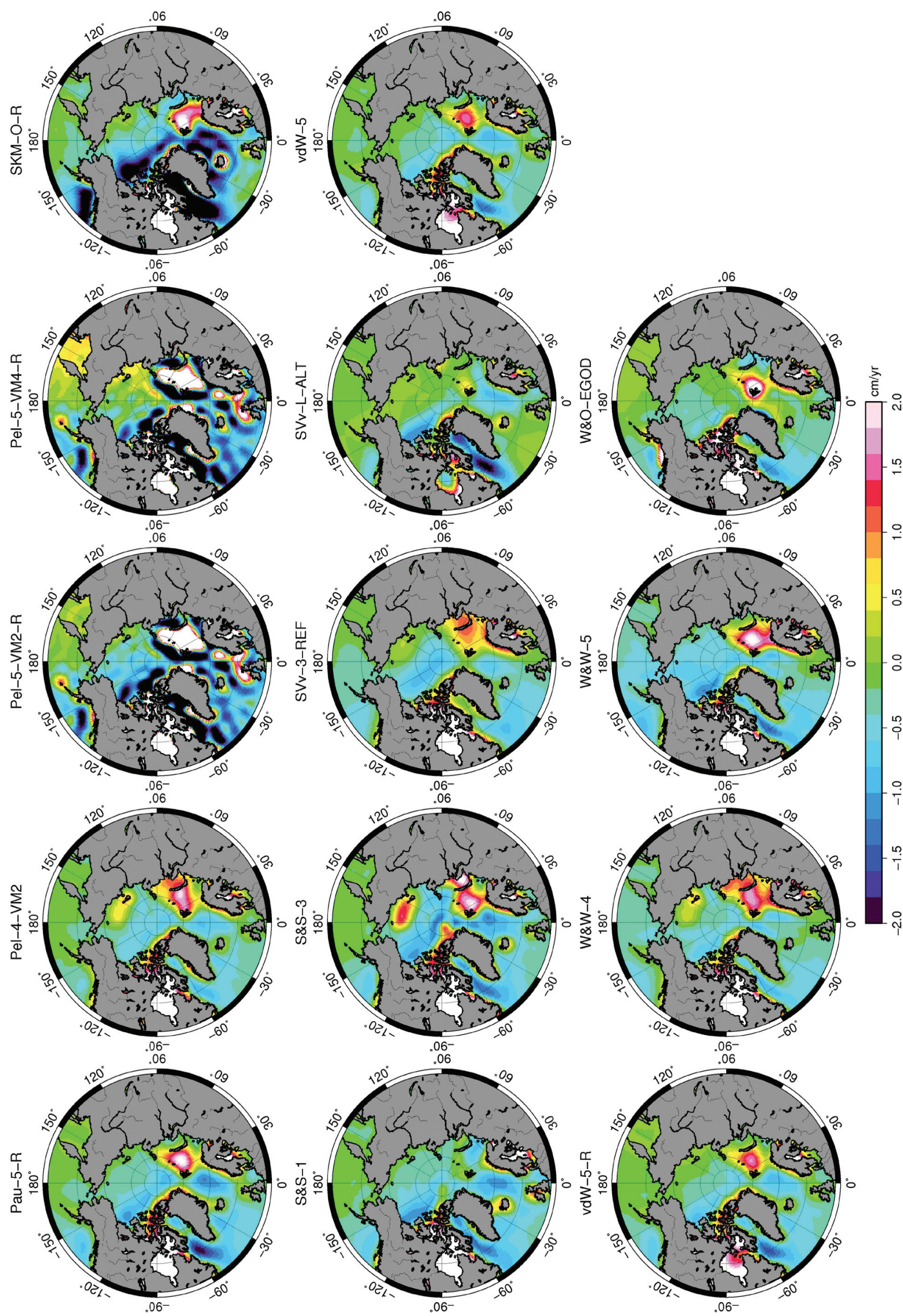

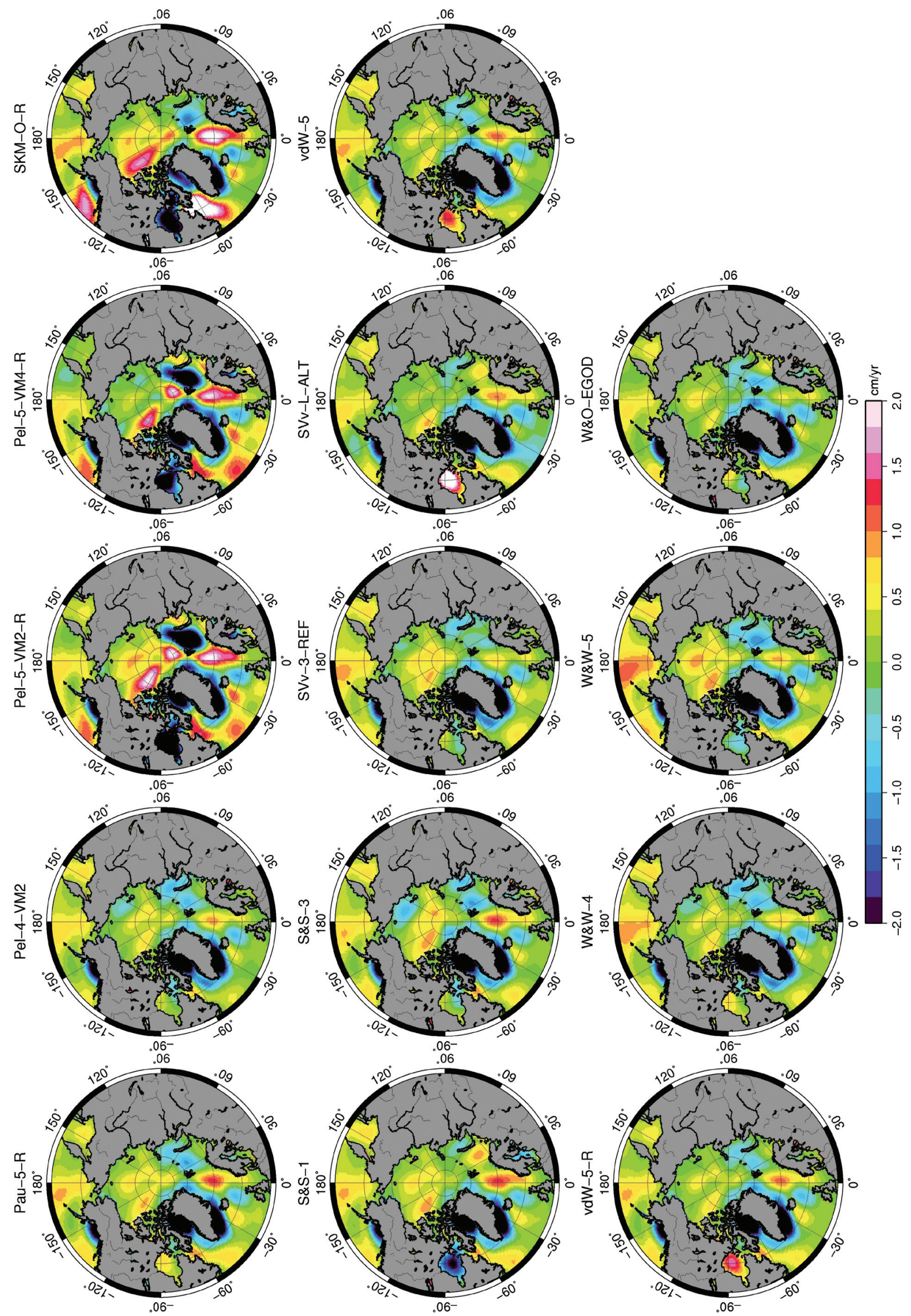
(2) The GIA contribution for satellite altimetry measurements is relatively small over the Arctic Ocean. Multisatellite derived mean sea-level trends are used in this study. After removing the GIA contribution, the sealevel trend $\left(2.73 \pm 0.11 \mathrm{~mm} \mathrm{yr}^{-1}\right)$ shows agreement with 10 selected tide gages derived from a secular sea-level trend $\left(2.02 \pm 1.02 \mathrm{~mm} \mathrm{yr}^{-1}\right)$ when averaged over the study region in the same time span.

(3) The GIA correction for GRACE over the Arctic Region is substantial, uncertainty of the GIA contribution to GRACE observation ranges from -5.76 to $1.31 \mathrm{~mm} \mathrm{yr}^{-1}$ for the entire Arctic Ocean. It is large enough to make this result to be GIA model dependent. Over the study region, the ocean mass component obtained from GRACE with GIA effect removed does not agree well with the steric-corrected altimeter result.

(4) GIA model predictions over the Arctic Ocean are significantly different, to study present day sea-level change in this region, further improvement in GIA modelling is needed.

Acknowledgements This research is partially supported by grants from NASA's Cryosphere program (NNX11AR47G and NNX10AG31G), the Ohio State University's Climate, Water, and Carbon program, and by the Chinese Academy of Sciences/SAFEA International Partnership Program for Creative Research Teams (Grant No. KZZD-EW-TZ-05). ZWH is partially supported under a scholarship by China Scholarship Council. We thank the GIA modellers for providing the models used in this study. Data sets used in this study are provided by AVISO (Altimetry), PSMSL (Tide gage) and NASA/DLR GRACE project via JPL PO-DAAC. Two anonymous reviewers provided suggestions that greatly improved the manuscript. Part of the figures in the paper is generated using GMT (Wessel and Smith 1998).

\section{REFERENCES}

Barry, R. G., M. C. Serreze, J. A. Maslanik, and R. H. Preller, 1993: The Arctic sea ice-climate system: Observations and modeling. Rev. Geophys., 31, 397-422, doi: 10.1029/93RG01998. [Link]

Bindoff, N., J. Willebrand, V. Artable, A. Cazenave, J. Gregory, S. Gulev, K. Hanawa, C. Le Quere, S. Levitus, Y. Nojiri, C. Shum, L. Talley, and A. Unnikrishnan, 2007: Observations: Oceanic climate change and sea level. In: Solomon, S., D. Qin, M. Manning, Z. Chen, M. Marquis, K. Averyt, M. Tignor, and H. Miller (Eds.), Climate Change 2007: The Physical Science Basis, Contribution of Working Group I to the Fourth Report of the Intergovernmental Panel on Climate Change, Cambridge University Press, Cambridge, UK \& NY.

Cazenave, A., K. Dominh, S. Guinehut, E. Berthier, W. Llovel, G. Ramillien, M. Ablain, and G. Larnicol, 2009:
Sea level budget over 2003-2008: A reevaluation from GRACE space gravimetry, satellite altimetry and Argo. Global Planet. Change, 65, 83-88, doi: 10.1016/j. gloplacha.2008.10.004. [Link]

Cheng, Y., O. B. Andersen, and P. Knudsen, 2012: First evaluation of MyOcean altimetric data in the Arctic Ocean. Ocean Sci.Discuss., 9, 291-314, doi: 10.5194/ osd-9-291-2012. [Link]

Duan, X. J., J. Y. Guo, C. K. Shum, and W. van der Wal, 2009: On the postprocessing removal of correlated errors in GRACE temporal gravity field solutions. J. Geodesy, 83, 1095-1106, doi: 10.1007/s00190-009-03270 . [Link]

Dziewonski, A. M. and D. L. Anderson, 1981: Preliminary reference earth model. Phys. Earth Planet. Inter., 25, 297-356, doi: 10.1016/0031-9201(81)90046-7. [Link]

Farrell, W. E. and J. A. Clark, 1976: On postglacial sea level. Geophys. J. R. Astr. Soc., 46, 647-667, doi: 10. 1111/j.1365-246X.1976.tb01252.x. [Link]

Guo, J. Y., X. J. Duan, and C. K. Shum, 2010: Non-isotropic Gaussian smoothing and leakage reduction for determining mass changes over land and ocean using GRACE data. Geophys. J. Int., 181, 290-302, doi: 10. 1111/j.1365-246X.2010.04534.x. [Link]

Guo, J. Y., Z. W. Huang, C. K. Shum, and W. van der Wal, 2012: Comparisons among contemporary glacial isostatic adjustment models. J. Geodyn., 61, 129-137 doi: 10.1016/j.jog.2012.03.011. [Link]

Ishii, M., M. Kimoto, K. Sakamoto, and S.-I. Iwasaki, 2006: Steric sea level changes estimated from historical ocean subsurface temperature and salinity analyses. $J$. Oceanogr., 62, 155-170, doi: 10.1007/s10872-006-00 41-y. [Link]

Jakobsson, M., R. Macnab, L. Mayer, R. Anderson, M. Edwards, J. Hatzky, H. W. Schenke, and P. Johnson, 2008: An improved bathymetric portrayal of the Arctic Ocean: Implications for ocean modeling and geological, geophysical and oceanographic analyses. Geophys. Res. Lett., 35, L07602, doi: 10.1029/2008gl033520. [Link]

Killett, B., J. Wahr, S. Desai, D. Yuan, and M. Watkins, 2011: Arctic Ocean tides from GRACE satellite accelerations. J. Geophys. Res., 116, C11005, doi: 10.10 29/2011JC007111. [Link]

Kuo, C. Y., 2006: Determination and characterization of 20th century global sea level rise, OSU Report \# 478, Geodetic Science and Surveying, Ohio State University.

Kuo, C. Y., C. K. Shum, J. Y. Guo, Y. Yi, A. Braun, I. Fukumori, K. Matsumoto, T. Sato, and K. Shibuya, 2008: Southern Ocean Mass Variation Studies Using GRACE and Satellite Altimetry. Earth Planets Space, 60, 477-485.

Kwok, R. and N. Untersteiner, 2011: The thinning of Arctic 
sea ice. Phys. Today, 64, 36-41, doi: 10.1063/1.35804 91. [Link]

Lambeck, K., C. Smither, and P. Johnston, 1998: Sea-level change, glacial rebound and mantle viscosity for northern Europe. Geophys. J. Int., 134, 102-144, doi: 10. 1046/j.1365-246x.1998.00541.x. [Link]

Lebedev, S. A., A. G. Kostianoy, A. I. GHinzberg, D. P. Medvedev, N. A. Sheremet, and S. N. Shauro, 2011: Satellite altimetry applications in the Barents and White Seas. In: Vignudelli, S., A. G. Kostianoy, P. Cipollini, and J. Benveniste (Eds.), Coastal Altimetry, Springer-Verlag Berlin Heidelberg, 578 pp.

Leuliette,E. W. and L. Miller, 2009: Closing the sea level rise budget with altimetry, Argo, and GRACE. Geophys. Res. Lett., 36, L04608, doi: 10.1029/2008GL036010. [Link]

Leuliette, E. W. and J. K. Willis, 2011: Balancing the sea level budget. Oceanography, 24, 122-129, doi: 10.56 70/oceanog.2011.32. [Link]

Mitrovica, J. X. and J. Wahr, 2011: Ice age earth rotation. Annu. Rev. Earth Planet. Sci., 39, 577-616, doi: 10.1146/annurev-earth-040610-133404. [Link]

Morison, J., J. Wahr, R. Kwok, and C. Peralta-Ferriz, 2007: Recent trends in Arctic Ocean mass distribution revealed by GRACE. Geophys. Res. Lett., 34, L07602, doi: 10.1029/2006GL029016. [Link]

Paulson, A., S. Zhong, and J. Wahr, 2007: Inference of manthe viscosity from GRACE and relative sea level data. Geophys. J. Int., 171, 497-508, doi: 10.1111/j.1365246X.2007.03556.x. [Link]

Peltier, W. R., 1994: Ice age paleotopography. Science, 265, 195-201, doi: 10.1126/science.265.5169.195. [Link]

Peltier, W.R., 1998: Postglacial variations in the level of the sea: Implications for climate dynamics and solid-Earth geophysics. Rev. Geophys., 36, 603-689, doi: 10.1029/ 98RG02638. [Link]

Peltier, W. R., 2001: Global glacial isostatic adjustment and modern instrumental records of relative sea level history. In: Douglas, B., M. Kearney, and S. Leatherman (Eds.), Sea Level Rise: History and Consequences, Int. Geophys. Ser., vol. 75, 37-64, Academic, San Diego, Calif.

Peltier, W. R., 2002: Global glacial isostatic adjustment: palaeogeodetic and space-geodetic tests of the ICE-4G (VM2) model. J. Quat. Sci., 17, 491-510, doi: 10.1002/ jqs.713. [Link]

Peltier, W. R., 2004: Global glacial isostasy and the surface of the ice-age earth: The ICE-5G (VM2) model and GRACE. Annu. Rev. Earth Planet. Sci., 32, 111-149, doi: 10.1146/annurev .earth.32.082503.144359. [Link]

Peltier, W. R., 2009: Closure of the budget of global sea level rise over the GRACE era: The importance and magnitudes of the required corrections for global glacial isostatic adjustment. Quat. Sci. Rev., 28, 1658-1674, doi: 10.1016/j.quascirev.2009.04.004. [Link]

Peltier, W. R. and J. T. Andrews, 1976: Glacial-isostatic adjustment - I. The forward problem. Geophys. J. R. Astr. Soc., 46, 605-646, doi: 10.1111/j.1365-246X.1976.tb 01251.x. [Link]

Peltier, W. R. and A. M. Tushingham, 1991: Influence of glacial isostatic adjustment on tide gauge measurements of secular sea level change. J. Geophys. Res., 96, 6779-6796, doi: 10.1029/90JB02067. [Link]

Peterson, B. J., J. McClelland, R. Curry, R. M. Holmes, J. E. Walsh, and K. Aagaard, 2006: Trajectory shifts in the Arctic and subarctic freshwater cycle. Science, 313, 1061-1066, doi: 10.1126/science.1122593. [Link]

Proshutinsky, A., V. Pavlov, and R. H. Bourke, 2001: Sea level rise in the Arctic Ocean. Geophys. Res. Lett., 28, 2237-2240, doi: 10.1029/2000GL012760. [Link]

Proshutinsky, A., I. M. Ashik, E. N. Dvorkin, S. Häkkinen, R. A. Krishfield, and W. R. Peltier, 2004: Secular sea level change in the Russian sector of the Arctic Ocean. J. Geophys. Res., 109, C03042, doi: 10.1029/ 2003JC002007. [Link]

Sasgen, I., V. Klemann, and Z. Martinec, 2012: Towards the inversion of GRACE gravity fields for present-day icemass changes and glacial-isostatic adjustment in North America and Greenland. J. Geodyn., 59-60, 49-63, doi: 10.1016/j.jog.2012.03.004. [Link]

Spada, G., V. R. Barletta, V. Klemann, R. E. M. Riva, Z. Martinec, P. Gasperini, B. Lund, D. Wolf, L. L. A. Vermeersen, and M. A. King, 2011: A benchmark study for glacial isostatic adjustment codes. Geophys. J. Int., 185, 106-132, doi: 10.1111/j.1365-246X.2011.04952. x. [Link]

Tamisiea, M. E., 2011: Ongoing glacial isostatic contributions to observations of sea level change. Geophys. $J$. Int., 186, 1036-1044, doi: 10.1111/j.1365-246X.2011. 05116.x. [Link]

Tamisiea, M. E. and J. X. Mitrovica, 2011: The moving boundaries of sea level change: Understanding the origins of geographic variability. Oceanography, 24, 2439, doi: 10.5670/oceanog.2011.25. [Link]

Tushingham, A. M. and W. R. Peltier, 1991: ICE-3G: A new global model of late pleistocene deglaciation based upon geophysical predictions of post-glacial relative sea level change. J. Geophys. Res., 96, 4497-4523, doi: 10.1029/90JB01583. [Link]

van der Wal, W., E. Kurtenbach, J. Kusche, and B. Vermeersen, 2011: Radial and tangential gravity rates from GRACE in areas of glacial isostatic adjustment. Geophys. J. Int., 187, 797-812, doi: 10.1111/j.1365-246X. 2011.05206.x. [Link]

Volkov, D. L. and M.-I. Pujol, 2012: Quality assessment of a satellite altimetry data product in the Nordic, Barents, and Kara seas. J. Geophys. Res., 117, C03025, doi: 10. 1029/2011JC007557. [Link] 
Wahr, J., H. DaZhong, and A. Trupin, 1995: Predictions of vertical uplift caused by changing polar ice volumes on a viscoelastic earth. Geophys. Res. Lett., 22, 977-980, doi: 10.1029/94GL02840. [Link]

Walsh, J., W. L. Chapman, and T. L. Shy, 1996: Recent decrease of sea level pressure in the central Arctic. $J$. Climate, 9, 480-486, doi: 10.1175/1520-0442(1996)00 9<0480:RDOSLP>2.0.CO;2. [Link]

Wahr, J., M. Molenaar, and F. Bryan, 1998: Time variability of the Earth's gravity field: Hydrological and oceanic effects and their possible detection using GRACE. J. Geophys. Res., 103, 30205-30229, doi: 10.1029/98 JB02844. [Link]

Wang, H. and P. Wu, 2006: Effects of lateral variations in lithospheric thickness and mantle viscosity on glacially induced surface motion on a spherical, self-gravitating Maxwell Earth. Earth Planet. Sci. Lett., 244, 576-589, doi: 10.1016/j.epsl.2006.02.026. [Link]

Wessel, P. and W. H. F. Smith, 1998: New, improved version of generic mapping tools released. Eos, Trans., $A G U, 79, \mathrm{p} 579$, doi: 10.1029/98EO00426. [Link]

Willis, J. K., D. P. Chambers, and R. S. Nerem, 2008: Assessing the globally averaged sea level budget on seasonal to interannual timescales. J. Geophys. Res., 113, C06015, doi: 10.1029/2007JC004517. [Link]

Wu, X., M. B. Heflin, H. Schotman, B. L. A., Vermeersen, D. Dong, R. S. Gross, E. R. Ivins, A. W. Moore, and S. E. Owen, 2010: Simultaneous estimation of global present-day water transport and glacial isostatic adjustment. Nat. Geosci., 3, 642-646, doi: 10.1038/ngeo938. [Link] 